Pacific Journal of Mathematic 


\title{
PLANAR CONTINUA WITH RESTRICTED LIMIT DIRECTIONS
}

\author{
C. L. Belna, M. J. Evans, and P. D. Humke
}

An affirmative answer is given to a question of D. M. Campbell and J. Lamoreaux concerning minimal conditions on the set of limit directions of a planar continuum that guarantee it is a line segment.

Throughout we let $E$ denote a planar continuum. The set $E$ is said to have a limit direction $e^{i \alpha}$ at the point $z$ in $E$ if there is a sequence of points $z_{n}$ in $E-\{z\}$ with $z_{n} \rightarrow z$ and $\left(z_{n}-z\right) /\left|z_{n}-z\right| \rightarrow$ $e^{i \alpha}$; this limit direction is called a right limit direction if we also have $\operatorname{Re}\left(z_{n}\right) \geqq \operatorname{Re}(z)$ for each $z_{n}$. The set of all [right] limit directions of $E$ at $z$ is denoted by $\mathscr{D}(z)\left[\mathscr{D}_{R}(z)\right]$ and is called the contingent of $E$ at $z$ in the older terminology of Saks [2].

D. M. Campbell and J. Lamoreaux [1] proved: Let $K$ be a subset of $E$ such that $\mathscr{D}(z) \cap\left\{e^{i \theta}: 0<|\theta| \leqq \pi / 2\right\}=\varnothing$ for each $z$ in $E-K$. If the projection of $K$ on the $y$-axis has measure zero, then $E$ is a horizontal line segment. Then they asked whether this theorem remains true when the condition on $\mathscr{D}(z)$ is replaced by the conition $\mathscr{D}_{R}(z) \subseteq\{1\}$. We now show this to be the case.

THEOREM. Let $K$ be a subset of $E$ such that $\mathscr{D}_{R}(z) \subseteq\{1\}$ for each $z$ in $E-K$. If the projection of $K$ on the $y$-axis has measure zero, then $E$ is a horizontal line segment.

Proof. To prove this theorem we show that the projection of $E$ on the $y$-axis is of measure zero.

One observes $\mathscr{D}_{R}(z) \subseteq\{1\}$ implies $\mathscr{D}(z) \cap\left\{e^{i \theta}: 0<|\theta|<\pi / 2\right\}=\varnothing$ and therefore for every point of $E-K$ the set $\mathscr{D}(z)$ cannot be the entire circle $\left\{e^{i \theta}: 0 \leqq \theta \leqq 2 \pi\right\}$. By the first fundamental theorem on contingents of plane sets ([2], p. 266), at every point of $E-K$, except those of a set $L$ of linear measure zero, the set $\mathscr{D}(z)$ is either a doubleton $\left\{e^{i \alpha},-e^{i \alpha}\right\}$ or a semicircle $\left\{e^{i \theta}: \alpha \leqq \theta \leqq \alpha+\pi\right\}$. Since $\mathscr{D}_{R}(z) \subseteq\{1\}$ on $E-K$, it follows that for each $z$ in $E-(K \cup L)$, the set $\mathscr{D}(z)$ is either the doubleton $\{i,-i\}$, the doubleton $\{1,-1\}$, or the $\operatorname{arc}\left\{e^{i \theta}: \pi / 2 \leqq \theta \leqq 3 \pi / 2\right\}$.

The second fundamental theorem on contingents of plane sets ([2], p. 267) asserts that $M \equiv\{z \in E-(K \cup L): \mathscr{D}(z)=\{1,-1\}\}$ has a projection on the $y$-axis of measure zero. Thus, to complete the proof we now show that the set $N \equiv E-(K \cup L \cup M)$ is countable. 
For each $z \in N, \mathscr{D}_{R}(z)=\varnothing$ and hence there is a rational number $r(z)$ and a corresponding closed half-disk

$$
D(z, r(z)) \equiv\{\zeta:-\pi / 2 \leqq \arg (\zeta-z) \leqq \pi / 2 \text { and }|\zeta-z| \leqq r(z)\}
$$

such that $D(z, r(z)) \cap E=\{z\}$. Also, for each rational number $r$ the set $N_{r} \equiv\{z \in N: r(z)=r\}$ is an isolated set, and the countability of $N$ is established.

In closing we note that in view of its proof, the theorem above remains true when the hypothesis $\mathscr{D}_{R}(z) \subseteq\{1\}$ is replaced by any condition which guarantees that if $z \in E-K$, then either (i) $\mathscr{D}_{R}(z)=\varnothing$ or (ii) $1 \in \mathscr{D}(z)$ and $\mathscr{D}(z)$ is a subset of either $\left\{e^{i \theta}: 0 \leqq\right.$ $\theta \leqq \pi\}$ or $\left\{e^{i \theta}: \pi \leqq \theta \leqq 2 \pi\right\}$.

\section{REFERENCES}

1. D. M. Campbell and J. Lamoreaux, Continua in the plane with limit directions, Pacific J. Math., 74 (1978), 37-46.

2. S. Saks, Theory of the integral, Monographie Matematyczne 7, Warszawa-Lwów, 1937.

Received June 8, 1978 and in revised form October 5, 1979.

Pennsylvania State University

UNIVERSITY PARK, PA 16802

Western IllinoIs UNIVERSity

Масомв, IL 61455

AND

Western Illinois University

Mасомв, IL 61455

Current address (C. L. Belna)

Syracuse University

Syracuse, NY 13210

Current address: (P. D. Humke)

St. Olaf College

Northfield, MN 55057 


\section{PACIFIC JOURNAL OF MATHEMATICS}

\section{EDITORS}

DONALD BABBITT (Managing Editor)

University of California

Los Angeles, CA 90024

Hugo RossI

University of Utah

Salt Lake City, UT 84112

C. C. MOORE and ANDREW OGG

University of California

Berkeley, CA 94720

\section{J. DugunduI}

Department of Mathematics

University of Southern California

Los Angeles, CA 90007

R. Finn and J. Milgram

Stanford University

Stanford, CA 94305

\section{ASSOCIATE EDITORS}
E. F. BeCKenBACH
B. H. NeumanN
F. WOLF
K. YosHIDA

\section{SUPPORTING INSTITUTIONS}



UNIVERSITY OF BRITISH COLUMBIA CALIFORNIA INSTITUTE OF TECHNOLOGY UNIVERSITY OF CALIFORNIA

MONTANA STATE UNIVERSITY

UNIVERSITY OF NEVADA, RENO

NEW MEXICO STATE UNIVERSITY

OREGON STATE UNIVERSITY UNIVERSITY OF OREGON

\author{
UNIVERSITY OF SOUTHERN CALIFORNIA \\ STANFORD UNIVERSITY \\ UNIVERSITY OF HAWAII \\ UNIVERSITY OF TOKYO \\ UNIVERSITY OF UTAH \\ WASHINGTON STATE UNIVERSITY \\ UNIVERSITY OF WASHINGTON
}

The Supporting Institutions listed above contribute to the cost of publication of this Journal, but they are not owners or publishers and have no responsibility for its content or policies.

Mathematical papers intended for publication in the Pacific Journal of Mathematics should be in typed form or offset-reproduced, (not dittoed), double spaced with large margins. Please do not use built up fractions in the text of the manuscript. However, you may use them in the displayed equations. Underline Greek letters in red, German in green, and script in blue. The first paragraph or two must be capable of being used separately as a synopsis of the entire paper. Please propose a heading for the odd numbered pages of less than 35 characters. Manuscripts, in triplicate, may be sent to any one of the editors. Please classify according to the scheme of Math. Reviews, Index to Vol. 39. Supply name and address of author to whom proofs should be sent. All other communications should be addressed to the managing editor, or Elaine Barth, University of California, Los Angeles, California, 90024.

50 reprints to each author are provided free for each article, only if page charges have been substantially paid. Additional copies may be obtained at cost in multiples of 50 .

The Pacific Journal of Mathematics is issued monthly as of January 1966. Regular subscription rate: $\$ 84.00$ a year (6 Vols., 12 issues). Special rato: $\$ 42.00$ a year to individual members of supporting institutions.

Subscriptions, orders for numbers issued in the last three calendar years, and changes of address shoud be sent to Pacific Journal of Mathematics, P.O. Box 969, Carmel Valley, CA 93924, U.S.A Old back numbers obtainable from Kraus Periodicals Co., Route 100, Millwood, NY 10546.

PUBLISHED BY PACIFIC JOURNAL OF MATHEMATICS, A NON-PROFIT CORPORATION

Printed at Kokusai Bunken Insatsusha (International Academic Printing Co., Ltd.). 8-8, 3-chome, Takadanobaba, Shinjuku-ku, Tokyo 160, Japan.

Copyright (C) 1980 by Pacific Jounal of Mathematics Manufactured and first issued in Japan 


\section{Pacific Journal of Mathematics \\ Vol. 90, No. $2 \quad$ October, 1980}

Frank Hayne Beatrous, Jr., Hölder estimates for the $\bar{\partial}$ equation with a support condition ..................................... 249

Charles L. Belna, Michael Jon Evans and Paul Humke, Planar continua

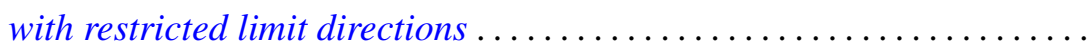

Leon Brown and Takashi Ito, Classes of Banach spaces with unique isometric preduals................................. 261

V. K. Deshpande, Completions of Noetherian hereditary prime rings ..... . 285

Deepak Dhar, Asymptotic enumeration of partially ordered sets . . . . . . . 299

Zeev Ditzian, On interpolation of $L_{p}[a, b]$ and weighted Sobolev

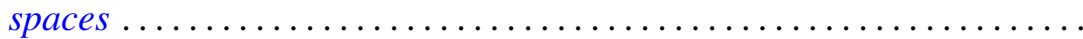

Andrew George Earnest, Congruence conditions on integers represented by

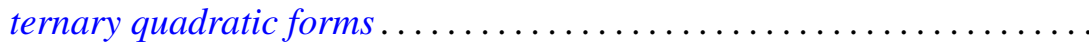

Melvin Faierman, Bounds for the eigenfunctions of a two-parameter system of ordinary differential equations of the second order ..............

Hector O. Fattorini, Vector-valued distributions having a smooth

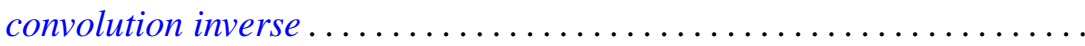

Howard D. Fegan, The spectrum of the Laplacian on forms over a Lie

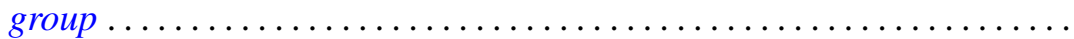

Gerald Leonard Gordon, On the degeneracy of a spectral sequence associated to normal crossings..

S. Madhavan, On bisimple weakly inverse semigroups ... 397

Françoise Mathot, On the decomposition of states of some

Roger McCann, Embedding asymptotically stable dynamical systems into radial flows in $l_{2}$

Michael L. Mihalik, Ends of fundamental groups in shape and proper homotopy...............................

Samuel Murray Rankin, III, Boundary value problems for partial functional differential equations .

Randy Tuler, Arithmetic sums that determine linear characters on $\Gamma(N)$

Jeffrey D. Vaaler, On linear forms and Diophantine approximation ..

G. P. Wene, Alternative rings whose symmetric elements are nilpotent or a right multiple is a symmetric idempotent. . 